\title{
O homem como agente transformador da paisagem
}

\section{Man as landscape transforming agent}

\author{
Enviado em: 30/11/2017 \\ Aceito em: 14/01/2018 \\ CARVALHO, Aline Beatriz Pacheco ${ }^{1}$ \\ ESCOBAR, Letícia Orling Camacho ${ }^{2}$ \\ CADEMARTORI, Cristina Vargas ${ }^{3}$
}

\section{Resumo}

Este ensaio visual evidencia modificações na paisagem natural no município de Glorinha, Rio Grande do Sul, a partir das interações entre os seres humanos e os ecossistemas naturais. Os registros fotográficos foram obtidos entre os meses de agosto a outubro de 2017, organizados e discutidos a partir de três eixos temáticos: paisagem natural, vestígios e impactos na paisagem. As fotografias demonstram a modelagem da paisagem de Glorinha ao longo do tempo e história do município.

Palavras-chave: Natureza; Cultura; Impacto.

\section{Abstract}

This visual essay intends to show some modifications of the natural landscape in the municipality of Glorinha, Rio Grande do Sul, caused by the interactions between humans and natural ecosystems. The photographic records were obtained between August and October 2017, organized and discussed from three thematic axes: natural landscape, traces and impacts on the landscape. The photographs show the modeling of the landscape of Glorinha over time and history of the municipality.

Keywords: Nature; Culture; Impact.

\footnotetext{
${ }^{1}$ Bolsista CAPES, doutoranda em Memória Social e Bens Culturais na Universidade La Salle. Bióloga no Centro de Estudos Ambientais Eco-Terrenão - Glorinha, RS. pacheco.carvalho@gmail.com

${ }^{2}$ Bolsista CAPES, mestranda em Avaliação de Impactos Ambientais na Universidade La Salle. Bióloga no Centro de Estudos Ambientais Eco-Terrenão - Glorinha-RS. leticia3344@yahoo.com.br

${ }^{3}$ Doutora professora Adjunta II da Universidade La Salle, PPG em Memória Social e Bens Culturais, Mestrado em Avaliação de Impactos Ambientais, Curso de Ciências Biológicas na Universidade La Salle. cristina.cademartori@unilasalle.edu.br
} 
Nas Ciências Geográficas, o conceito de paisagem sempre esteve associado às discussões reflexivas voltadas à Geografia Cultural, que considera os valores e significados atribuídos às paisagens como resultado do vínculo afetivo entre as sociedades humanas e os locais onde vivem. Os grupos selecionam os elementos da paisagem a partir de um sentido ou utilidade atribuída a sua realidade (SOUZA, 2011). Tais elementos, escolhidos arbitrariamente e justificados pelo caráter estético ou utilitário, passam a compor o cenário da paisagem que, por vezes, também é moldado pelos limites ou desafios impostos pela Natureza. A partir desta relação, a paisagem cultural é modelada por um grupo cultural, tendo como cenário a paisagem natural.

A paisagem cultural é o produto de ações dinâmicas que representam as concepções de grupos em determinados momentos. Ela é modelada a partir de uma paisagem natural, onde a cultura se torna o agente e a paisagem cultural o resultado, fruto da interação entre as partes. Como consequência destas interações ser humanonatureza e das interferências crescentes no ambiente, exige-se cada vez mais recursos do território em escala incompatível com a capacidade de resiliência ${ }^{4}$ da natureza (RISSO, 2008). Então, sob a influência de determinada cultura o cenário da paisagem se modifica, pois, alguns elementos são suprimidos em favor de outros que possuam a representatividade legítima do grupo social que ali se estabelece (SAUER, 1998). Neste sentido, a natureza participa passivamente da modelagem da paisagem que se altera a partir das necessidades da população humana. Logo, encontra-se aí o importante desafio de conciliar as necessidades humanas, a conservação da natureza e a ética.

O objetivo deste ensaio visual é apresentar registros que evidenciam as modificações da paisagem natural no município de Glorinha, Rio Grande do Sul, a partir das interações entre a comunidade local e os ecossitemas naturais. Os registros fotográficos foram obtidos pelas próprias autoras entre os meses de agosto a outubro de 2017, organizados e discutidos a partir de três eixos temáticos: paisagem natural, vestígios e impactos na paisagem. Relatos orais foram utilizados como fontes para fundamentação da descriçãoque acompanha as fotografias.

\section{Paisagem Natural}

Dean (1996) é afirmativo quando sugere que a compreensão da natureza não deve ser limitada por conceitos ou significados atribuídos desde um ponto de vista

\footnotetext{
${ }^{4}$ Capacidade que o ambiente tem de receber impactos e assimilá-los, retornando ao equilíbrio. ODUM, 1983.
} 


\section{Revista méría}

antropocentrista, em que o meio natural é considerado apenas como reserva de recursos econômicos ou como cenário onde se desenvolvem e manifestam diferentes práticas culturais. A paisagem fornece, portanto, um modelo para pensar a complexidade da natureza, que convida a refletir sobre os aportes diferentes da ciência, do ser humano e da sociedade numa perspectiva sustentável.

O município de Glorinha ainda conserva paisagens onde é possível identificar testemunhos de espécies da flora nativa (figuras 1 e 2). Em sua extensão de 323,6 quilômetros quadrados, a paisagem divide-se entre sítios de lazer, fazendas com criação de animais, um mosaico de cultivos agrícolas variados e remanescentes florestais naturais, além de cascatas e um pequeno cânion (figura 3). Atualmente, cerca de $97 \%$ do território do município de Glorinha encontram-se inseridosem uma unidade de conservação de uso sustetável (figura 4).

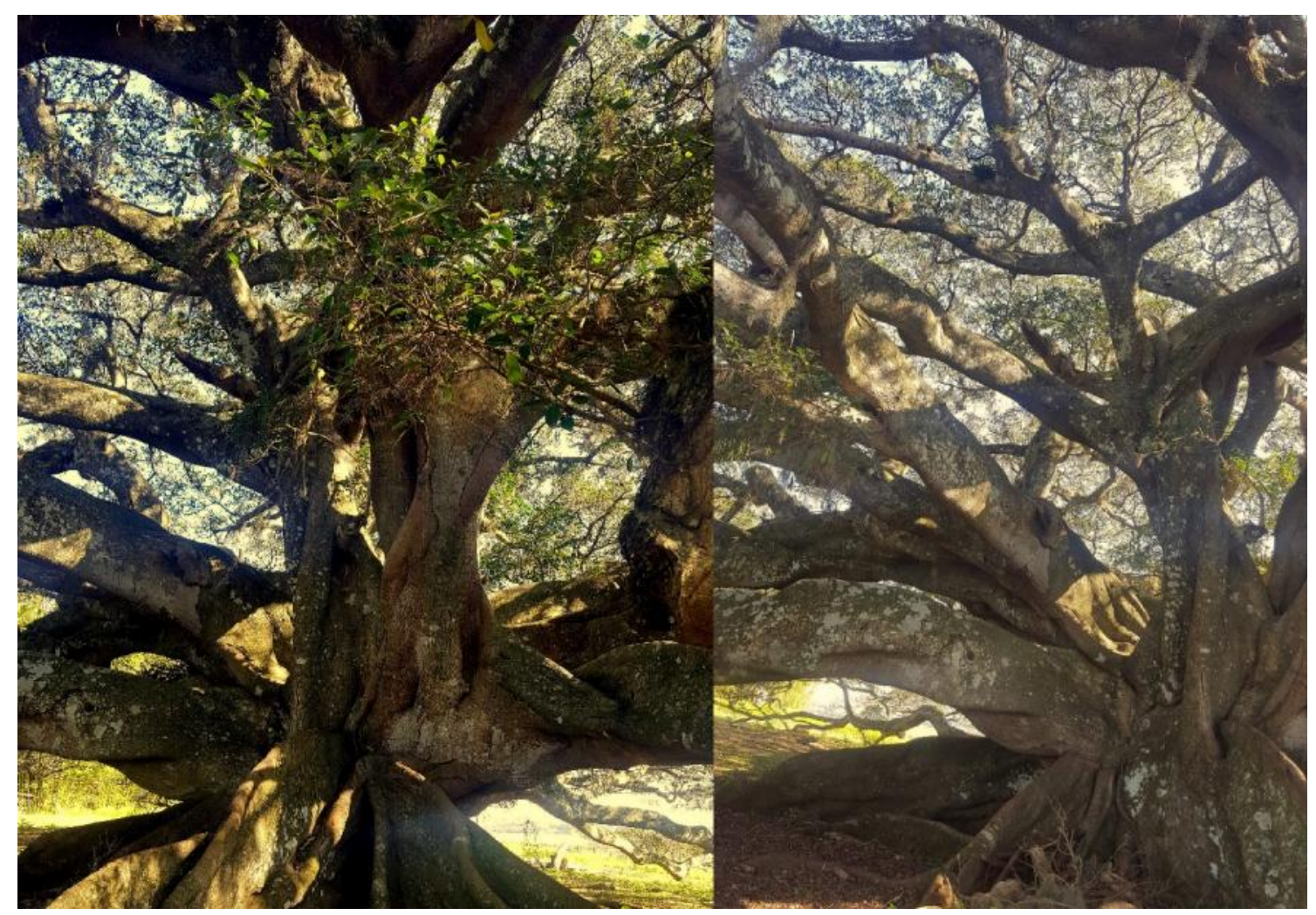

Figura 1. Figueira centenária: antigos habitantes de Glorinha/RS plantaram figueiras nativas em diferentes locais da Sede Municipal. O nome dos plantadores: Garibaldino Ferrugem, Salustiano Jacques, Deoclécio Ferrugem, José Alves Pereira, Otacílio Soares e Eduardo Ferrugem. Pela importância atribuída a esta árvore, as figueiras simbolizam a "consciência ecológica" dos habitantes desde meados do século XX, estando presente no brasão do município (KNOBELOCH, 2008). Localidade: Capão Grande, Glorinha, RS. Fonte: Letícia Orling Camacho Escobar. Ano: 2017. 


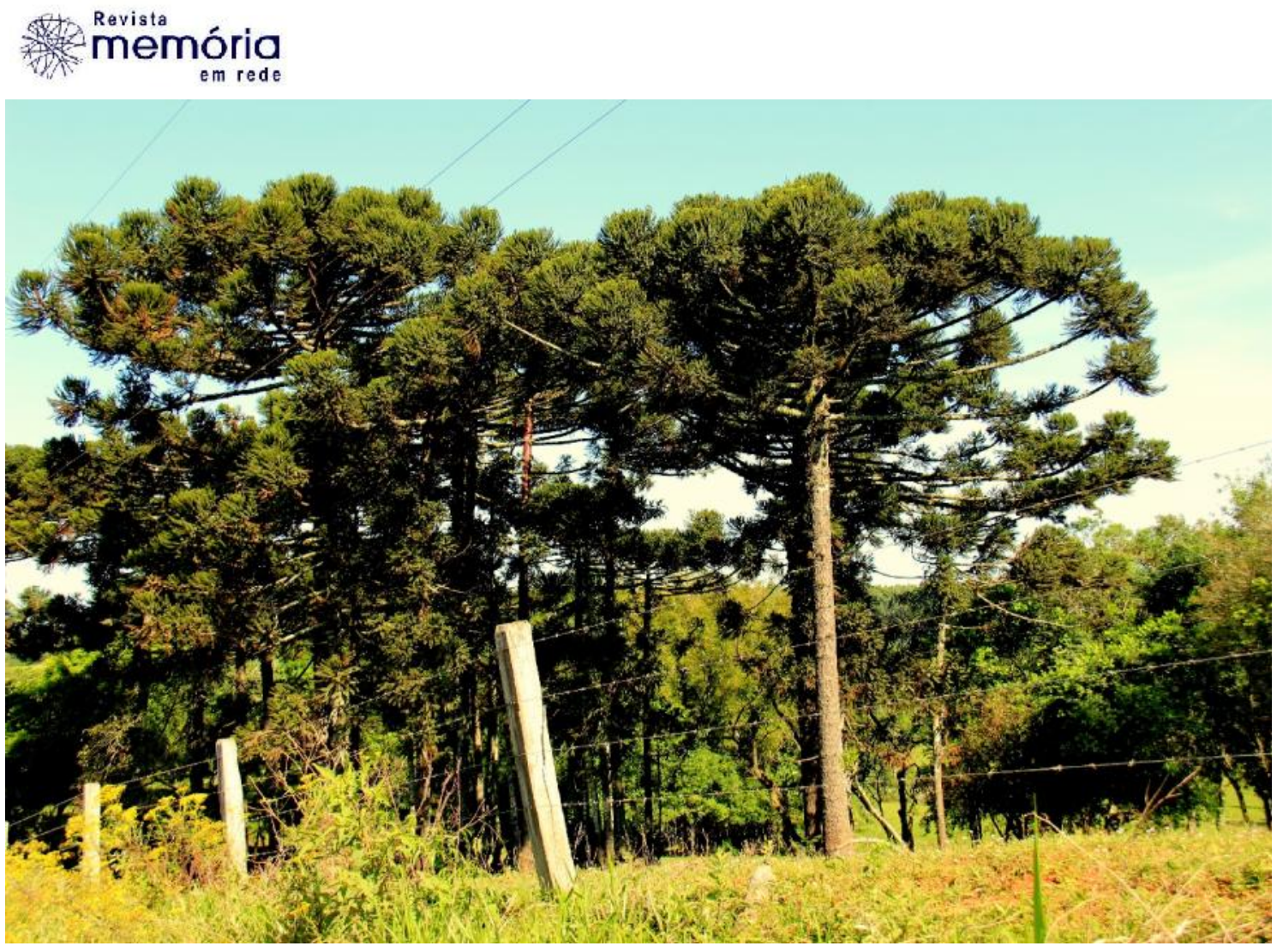

Figura 2. Pinheiros nativos do RS (Araucariaangustifolia), característicos da Floresta Ombrófila Mista. Desde o início da colonização, a Floresta Ombrófila Mista, assim como todos os demais sistemas florestais do Estado do Rio Grande do Sul, foi exaustivamente explorada (HUECK, 1972). Atualmente, a espécie Araucaria angustifólia é considerada ameaçada no Estado, na categoria Vulnerável. Localidade: limite entre Glorinha e Santo Antônio da Patrulha, RS. Fonte: Aline Beatriz Pacheco Carvalho. Ano: 2017. 


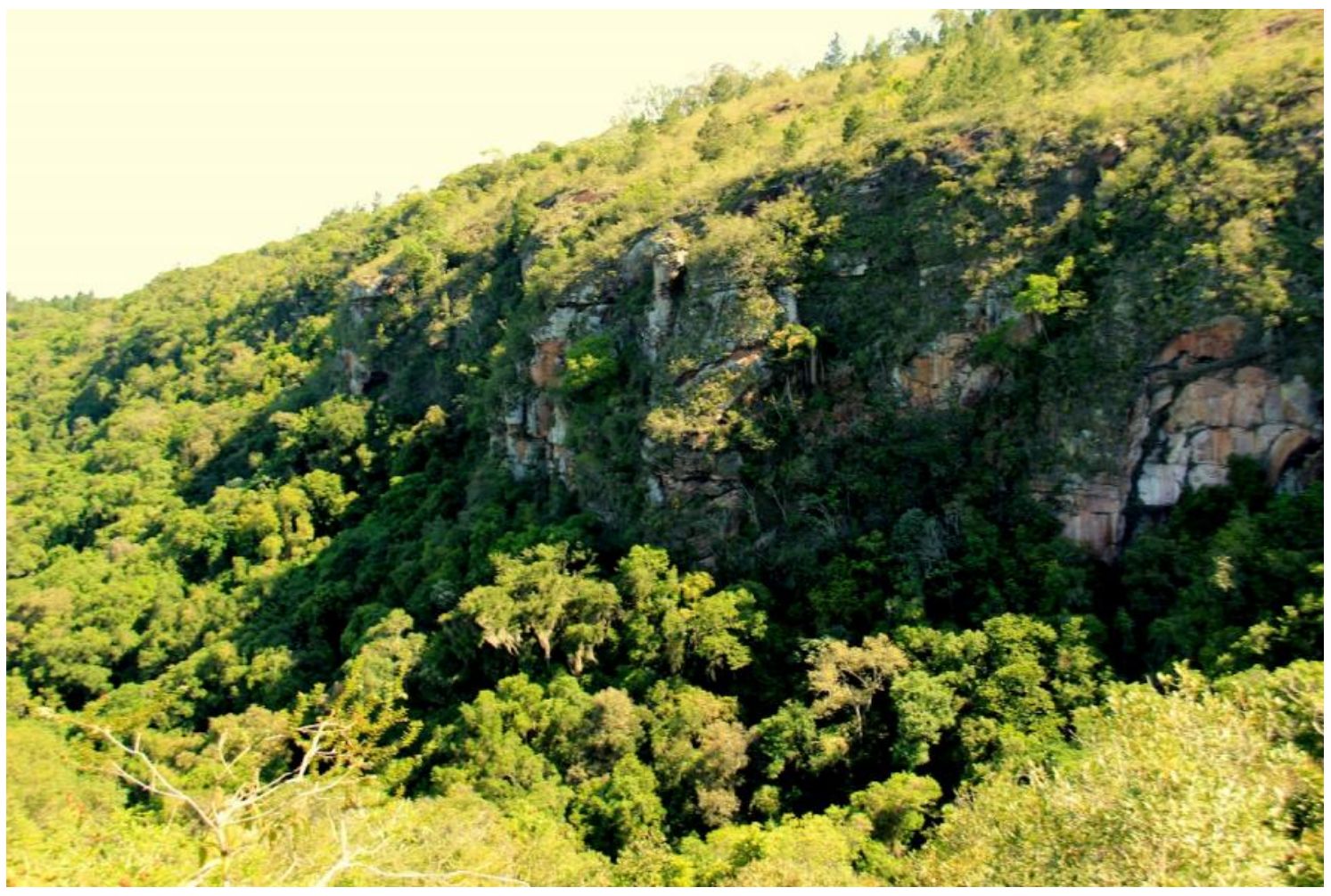

Figura 3. Cânion de Glorinha, RS.Desde quando a terra se diferenciou em litosfera, hidrosfera e atmosfera há mais de 4 bilhões de anos é que estes processos ditaram a evolução biológica e geológica do planeta (TEIXEIRA et al.2003). Aqui podemos admirar a vista vertical deste paredão rochoso que forma esta paisagem deslumbrante, e de contagiante sensação de paz com a natureza. Vista apreciada por turistas e principalmente pelos glorienses (fonte oral: Rafael Schimidt, 2017. Localidade: Imbiruçu.Fonte: Aline Beatriz Pacheco Carvalho. Ano: 2017.

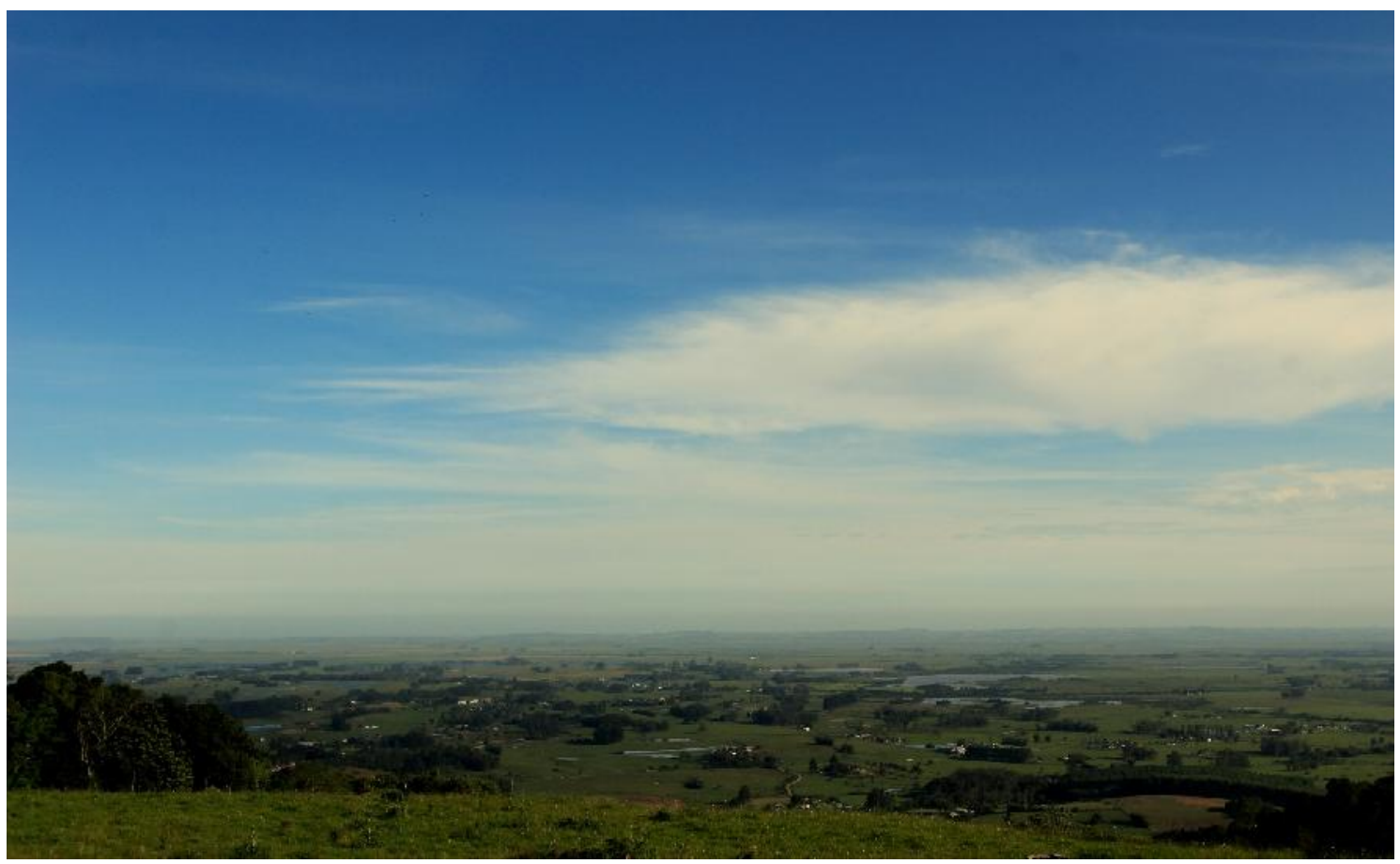

Revista Memória em Rede, Pelotas, v.10, n.18, Jan./Jul.2018 - ISSN- 2177-4129 
Figura 4:Costa da Miraguaia. Vista panorâmica da Região do Banhado Grande. Localizada na unidade lagunar, na porção central da bacia do rio Gravataí. Apresenta relevo plano e lençol freático raso, razão pela qual a região está sujeita a inundações sazonais. O Banhado Grande é o importante receptor das águas contribuintes da Coxilha das Lombas, da região de Santo Antônio da Patrulha e das rochas da Formação Serra Geral e Botucatu (Rio Grande do Sul, 2012). Em 1998, foi criada, pelo Decreto Estadual n 38.971, a Área de Proteção Ambiental do Banhado Grande, no intuito de salvaguardar a biodivesridade e as principais nascentes responsáveis pela formação do rio Gravataí. Fonte: Aline Beatriz Pacheco Carvalho. Ano: 2017.

\section{Vestígios na paisagem}

A paisagem reflete a realidade do espaço que foi construído ao longo da existência humana,considerando a forma como as pessoas vivem ou viveram. Reflete, ainda, o tipo de relação que existe entre elas e a que se estabelece com a natureza. Sendo assim, o lugar mostra, através da paisagem, a história da população que ali vive, os recursos naturais de que dispõe e a forma como são utilizados tais recursos (CALLAI, 2000).

Diferentes etnias contribuíram para a concepção cultural do município de Glorinha, entre elas, índios Guarani, negros quilombolas, portugueses, açorianos e alemães (KNOBELOCH, 2008), que deixaram suas marcas, impressões e vestígios na paisagem do município (figuras 5 e 6 ).

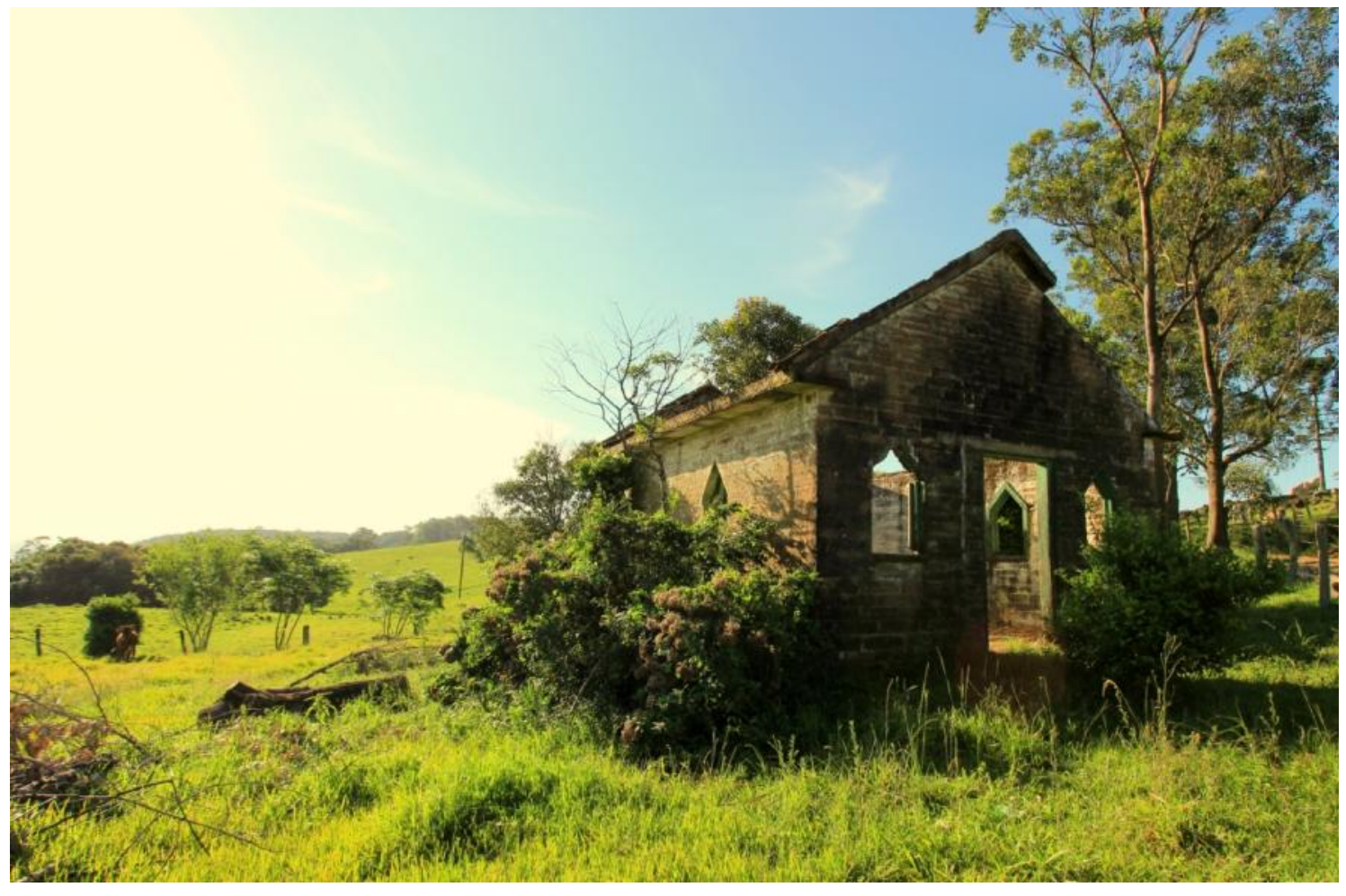

Figura 5:Vestígio na paisagem: pintores paisagistas começaram a enxergar as árvores como temas a serem incluídos em seus quadros no século XIX. Mais tarde os Impressionistas recriavam suas obras com jogo de luz, ressaltando o vínculo entre o homem e a natureza (LIEUTAGHI,2012). Aqui avista-se uma 
paisagem digna de uma pintura em tela, onde a natureza começou a reocupar o espaço físico e ocultar os vestígios deixados pelos imigrantes da região, em consequência de abandono.Fonte: Aline Beatriz Pacheco Carvalho. Ano: 2017.
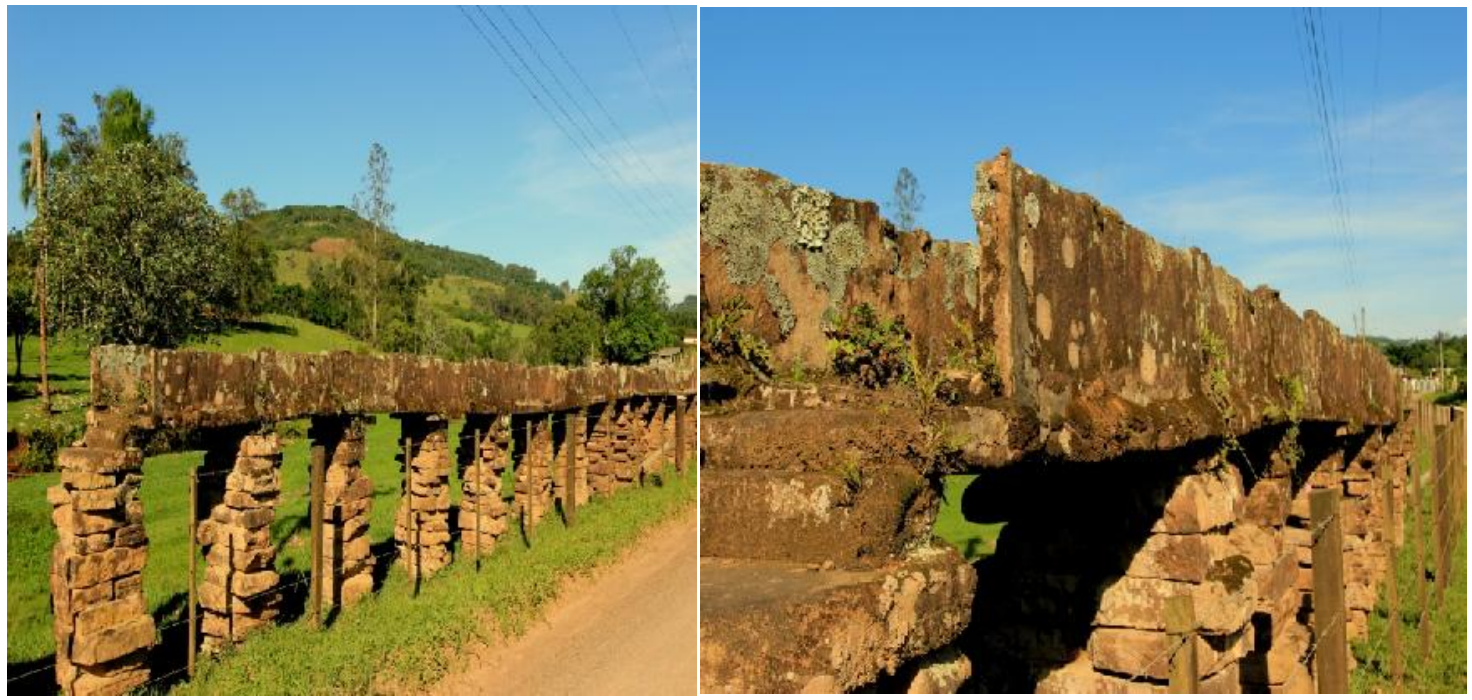

Figura 6: Aqueduto: canal ao ar livre utilizado para conduzir água por gravidade de um lugar ao outro. Analisando a utilização dos recursos naturais, encontram-se aqui as marcas de uma cultura abandonada pelo tempo: uma obra arquitetônica de rara beleza localizada entre os municípios de Glorinha e Santo Antônio da Patrulha, RS. Desde as mais remotas civilizações há indícios e relatos das edificações destinadas à condução de água, mostrando que a natureza esteve a serviço do ser humano, fornecendo recursos em diferentes ecossistemas. Fonte: Aline Beatriz Pacheco Carvalho. Ano: 2017.

\section{Impactos na paisagem}

Os impactos ambientais refletem as alterações no meio ambiente causadas por alguma atividade antrópica. Os impactos podem levar à degradação quandoo ambiente perde sua cobertura vegetal e sua capacidade de regeneração (CARPANEZZI, 1990). Portanto, a destruição da camada fértil do solo são sintomas de degradação. Dentre as atividades exploradoras que impactam e degradam o meio ambiente está a mineração. Nesta, os efeitos ambientais negativos estão associados às diversas fases de exploração, desde a abertura da cava (remoção da vegetação, escavações, deslocamento de solo e modificação da paisagem local), uso de explosivos no desmonte de rocha,afugentamento da fauna, supressão da vegetação nativa, ao transporte e beneficiamento do minério (MECHI, SANCHES, 2010; BACCI, 2006).

Na localidade de Maracanã, observa-se o impacto e a degradação ambiental decorrente de, aproximadamente, cinquenta anos de atividade exploratória de mineração. Atualmente, a cava encontra-se desativada e abandonada. Porém, a ausência da cobertura original do solo e a presença de vegetação exótica (espécie de 


\section{memória}

pinheiro da América do Norte, Pinnus sp.) evidenciam os passivos ambientais deixados na paisagem (figura 7).

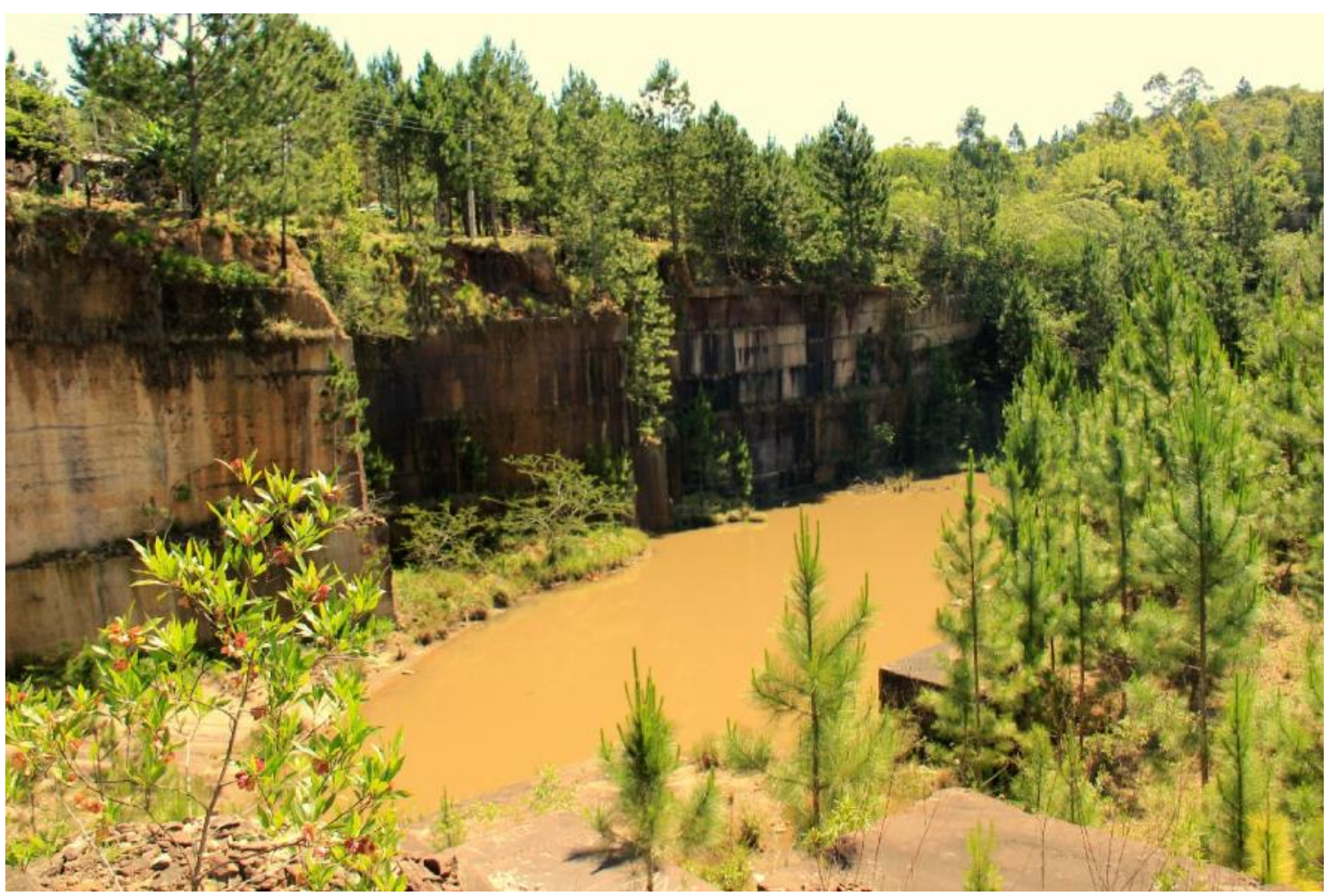

Figura 7. Pedreira do Maracanã. Conforme fonte oral (Rafael Schimidt, 2017), as atividades iniciaram em meados de 1950 e o seu funcionamento cessou em 2005 devido à intervenção do órgão ambiental Fundação Estadual de Proteção Ambiental Henrique Luís Roessler (FEPAM, RS). A matéria-prima extraída era pedra Grés. Localidade: Maracanã, Glorinha, RS. Foto: Aline Beatriz Pacheco Carvalho. Ano: 2017.

\section{Considerações finais}

Desde os primórdios a relação da espécie humana com a natureza é marcada pela busca e a competição por recursos naturais para a sua subsistência (RIBEIRO, CAVASSAN, 2012). A história da civilização humana nos leva a refletir sobre o tipo de relação que estabelecemos com a paisagem e a natureza (BERTRAND, 1971), que resulta, ainda hoje, em uma relação extrativista e carente de planejamento sustentável. Os registros fotográficos obtidos evidenciam a modelagem da paisagem de Glorinha pelos seus habitantes ao longo do tempo. A paisagem revela-se marcada por aspectos históricos e formada por um mosaico de atividades antrópicas presentes no 
limiar tênue entre o desenvolvimento econômico e a sustentabilidade. Acreditase que a reflexão sobre as ações locais contribua para mudanças globais, especialmente no que diz respeito à conciliação entre os interesses humanos e a conservação da natureza, pautada em princípios éticos, no conceito de sustentabilidade e na ideia de que toda a vida na Terra, inclusive a humana, tem um destino comum.

\section{Referências}

BACCI, D. DE LA C., LANDIM, P. M. B., ESTON, S. M. DE. Aspectos e impactos ambientais de pedreira em área urbana. REM: R. Esc. Minas, Ouro Preto, 59(1): 4754. 2006.

BERTRAND, G. Paisagem e geografia física global: esboço metodológico. Cadernos de Ciências da Terra, n. 13, Instituto de Geografia da USP, 1971, 27p. (Trad. Paysage et géographie physique globale: esquisse méthodologique, 1968).

CALLAI, H. C. Estudar o lugar para compreender o mundo. In: CASTROGIOVANNI, A. C. (Org.) Ensino de Geografia: práticas e textualizações no cotidiano. Porto Alegre,

Mediação, 2000.

CARPANEZZI, A. A. et al. Espécies pioneiras para recuperação de áreas degradadas, observações de laboratórios naturais. In: CONGRESSO FLORESTAL BRASILEIRA, 6., 1990, Campos do Jordão. Anais. Campos do Jordão: (s.n), 1990. P. 2016-221.

DEAN, Warren. 1996. A ferro e fogo: a história e a devastação da Mata Atlântica brasileira. 1 ed. São Paulo: Cia. das Letras, 2004. 484 p.

HUECK, K.As florestas da América do Sul: ecologia, composição e importância econômica. São Paulo, Polígono.1972

KNOBELOCH, M. D. R. Traços Do Discurso Religioso Fundador De Glorinha/Rs: Suas Histórias E Aspectos Religiosos. Dissertação de Mestrado (Escola Superior de Teologia Instituto Ecumênico de Pós-Graduação). São Leopoldo. 2008.

LIEUTAGHI, Pierre. Árvores. 1. ed. São Paulo: Publifolha, 2012.

MECHI, A., SANCHES, D. L. Impactos ambientais da mineração no Estado de São Paulo. Estudos avançados. vol.24 no.68. São Paulo, 2010.

ODUM, E. P. Ecologia. Rio de Janeiro: Guanabara, 1983.

RIBEIRO, Job Antonio Garcia, CAVASSAN, Osmar. Um olhar epistemológico sobre o vocábulo ambiente: algumas contribuições para pensarmos a ecologia e a educação ambiental. Filosofia e História da Biologia, v. 7, n. 2, p. 241-261, 2012. 
RIO GRANDE DO SUL. Plano de recursos hídricos da Bacia Hidrográfica do rio Gravataí. Secretaria do Meio Ambiente. 2012.

RISSO, L. C. Paisagens e Cultura: uma reflexão teórica a partir do estudo de uma comunidade indígena amazônica. Espaço e Cultura, n. 23, p. 67-76, 2008.

SAUER, C. O. A morfologia da Paisagem. In: CORRÊA, R. L; ROSENDAHL, Z. (Orgs.). Paisagem, tempo e cultura. Rio de Janeiro: EdUERJ, 1998. p. 12-74.

SOUZA, L. A. Dean, Warren. A Ferro e Fogo: a história da devastação da Mata Atlântica brasileira. AEDOS, Revista do corpo discente do PPG - História da UFRGS, v. 3, n. 8, 2011.

TEIXEIRA, W. ; TOLEDO, M.C.M.; FAIRCHILD, T. R.;TAIOLE,F. Decifrando a terra. São Paulo: Oficina de Texto,2003. 